Article

\title{
Synthetic Bio-Graphene Based Nanomaterials through Different Iron Catalysts
}

\author{
Qiangu Yan ${ }^{1,+}$, Jinghao $\mathrm{Li}^{2,+}$, Xuefeng Zhang ${ }^{1} \mathbb{C}$, Jilei Zhang ${ }^{1, *}$ and Zhiyong Cai ${ }^{2, *}$ \\ 1 Department of Sustainable Bioproducts, Mississippi State University, Starkville, MS 39762, USA; \\ yanqiangu@gmail.com (Q.Y.); xz210@student.exchange.msstate.edu (X.Z.) \\ 2 Forest Products Laboratory, USDA Forest Service, Madison, WI 53726, USA; jli@fs.fed.us \\ * Correspondence: jz27@msstate.edu (J.Z.); zcai@fs.fed.us (Z.C.) \\ + These authors contributed equally to this work.
}

Received: 25 September 2018; Accepted: 11 October 2018; Published: 16 October 2018

\begin{abstract}
Kraft lignin was catalytically graphitized to graphene-based nanostructures at $1000{ }^{\circ} \mathrm{C}$ under argon atmosphere with four iron catalysts, iron(III) nitrate (Fe-N); iron(II) chloride ( $\left.\mathrm{Fe}^{-\mathrm{Cl}} \mathrm{l}_{2}\right)$; iron(III) chloride $\left(\mathrm{Fe}_{-} \mathrm{Cl}_{3}\right)$; and iron(II) sulfate (Fe-S). The catalytic decomposition process of iron-promoted lignin materials was examined using thermalgravimetric analysis and temperature-programmed decomposition methods. The crystal structure, morphology and surface area of produced materials were characterized by means of X-ray diffraction, Raman, scanning electron microscopy, high resolution transmission electron microscopy and $\mathrm{N}_{2}$ adsorption-desorption techniques. Experimental results indicated that iron nitrate catalyst had better iron dispersion three other iron salts. Iron nitrate was the most active catalyst among four iron salts. The low activity of iron in iron chloride-promoted samples was because the residual chlorine over iron surfaces prevent iron interaction with lignin functional groups.
\end{abstract}

Keywords: kraft lignin; catalytic thermal decomposition; carbon-based nanomaterials; iron(III) nitrate; iron(II) sulfate; iron(II) chloride; iron(III) chloride

\section{Introduction}

Lignin is a substance in the cell walls of plants that strengthens their structure. During paper pulping processes, lignin is produced as a byproduct. Approximately 50-70 million tons of kraft lignin and 1.8 million tons of lignosulfonates are produced worldwide annually and only about $2 \%$ of this amount are utilized for the production of value-added products [1]. Lignosulfonates have a wide variety of applications such as dispersing pesticides, dyes and carbon black; making concrete as plasticizers and fine chemicals as a feedstock [2]. The majority of kraft lignin is used as a low-grade fuel burned on site during kraft pulping operations [2]. Researchers have been trying to valorize lignin waste streams to useful chemicals or materials for large-scale industrial applications.

Lignin contains approximately $60 \%$ carbon and can be a carbon precursor for producing templated carbons [3], carbon fibers [4] and activated carbon [5]. A process has been developed to turn kraft lignin into carbon-based nanostructures, that is, graphene-encapsulated nanoparticles [6,7] and graphene materials $[8,9]$. Kraft lignin was catalytically converted to these carbon-based nanomaterials at high temperature under different atmospheres [9]. Transitional metals such as iron, copper, nickel and molybdenum as catalysts were very active for graphitization of solid carbon materials like kraft lignin $[10,11]$ but their chemical compounds can have different catalytic activities. The catalytic activity of any transitional metal in a solid carbon material is governed by its oxidation state and active specific area, that is, its dispersion in the solid carbon material. It is also affected by the poison species in the reactants, that is, a metal catalyst can be deactivated by poisoning species like sulfur, halides 
and other residual impurities. On the other hand, the starting state of an active metal can play a significant role in the catalytic performance [12]. The substitution of a transitional metal using its chemical compound to a solid carbon source, as these two are mixed to form a precursor, can lead the formation of different metal phases in terms of different particle sizes and therefore can influence the surface atomic composition of the metal as a catalyst.

Therefore, it is desirable to investigate the effects of different chemical compounds containing the same transitional metal mixed with kraft lignin as precursors on catalytic graphitization of kraft lignin as a carbon in order to find the optimum method for preparing efficient catalysts. Specifically, in this study, the effects of four iron salts, iron nitrate (Fe-N), iron(II) chloride ( $\left.\mathrm{Fe}^{-} \mathrm{Cl}_{2}\right)$, iron(III) chloride $\left(\mathrm{Fe}-\mathrm{Cl}_{3}\right)$ and ferrous sulfate (Fe-S) as metal catalyst sources on catalytic carbonization of kraft lignin were investigated.

\section{Experimental}

\subsection{Iron-Lignin Precursor Preparation}

Kraft lignin used in this study as a carbon source was BioChoice Lignin supplied by Domtar Corp., Plymouth, NC, USA. Four analytical grade iron salts, iron(III) nitrate; iron(II) chloride; iron(III) chloride; and iron(II) sulfate purchased from Sigma-Aldrich, Inc. (St. Louis, MO, USA), were used in this study as metal catalyst sources. These iron salts have different physical-chemical properties like solubility and thermal stability [13]. Iron-lignin precursors with their mass ratio of 1/9 (1 part iron and 9 parts lignin) were prepared at room temperature using a co-precipitation technique. Specifically, lignin solution was prepared by adding $300 \mathrm{~g}$ of kraft lignin to $300 \mathrm{~mL}$ tetrahydrofuran (THF) in a 2000-mL glass beaker and stirring the mixture for $2 \mathrm{~h}$. Iron nitrate solution was prepared by adding $246.0 \mathrm{~g}$ of iron(III) nitrate nonahydrate to $100 \mathrm{~mL}$ DI water in a 500-mL glass beaker and stirring the mixture until the metal salt dissolved completely. Prepared iron nitrate solution drop-like $(\sim 2 \mathrm{~mL} / \mathrm{min})$ was added to the lignin solution and the lignin-iron nitrate mixture was stirred for $2 \mathrm{~h}$. The final iron-lignin mixture was kept at room temperature for $24 \mathrm{~h}$ and then transferred to an oven and dried at $110{ }^{\circ} \mathrm{C}$ for one day. After drying process, a solid iron-promoted lignin mixture as a precursor was obtained. The same mixing and drying procedure was performed to other three iron salts, iron(II) chloride, iron(III), iron(III) chloride and iron(II) sulfate.

\subsection{Catalytic Graphitization}

For each thermal treatment run, $15 \mathrm{~g}$ of an iron-promoted lignin precursor were packed in the middle of a 1-inch OD ceramic tubular reactor (McDanel Advanced Ceramic Technologies LLC, Beaver Falls, PA, USA). The carrier argon ( $99.9 \%$ purity) gas was first introduced into the reactor at a flow rate of $50 \mathrm{~mL} / \mathrm{min}$ for $30 \mathrm{~min}$. The reactor was heated at a rate of $10{ }^{\circ} \mathrm{C} / \mathrm{min}$ to $1000{ }^{\circ} \mathrm{C}$ and kept at $1000{ }^{\circ} \mathrm{C}$ for $1 \mathrm{~h}$. The furnace was cooled down by $10^{\circ} \mathrm{C} / \mathrm{min}$ to room temperature.

\subsection{Thermogravimetric Analyses (TGA)}

TGA analyses of iron-promoted lignin precursors were carried out in a TGA (Shimadzu TGA-50H, Columbia, MD, USA) through isothermal analyses. For each run, $10 \mathrm{mg}$ of iron-promoted lignin mixtures were loaded with argon $(99.99 \%$ purity, $50 \mathrm{~mL} / \mathrm{min}$ ) gas flowing through the TGA at $50 \mathrm{~mL} / \mathrm{min}$ as temperature was ramped at $10{ }^{\circ} \mathrm{C} / \mathrm{min}$. Three replicates were evaluated for each of four iron-promoted lignin precursors.

\subsection{Temperature-Programmed Decomposition (TPD) Analyses}

TPD analyses of raw kraft lignin and iron-promoted lignin precursors were carried out using an Autochem II 2920 system connected to an on-line residue gas analyzer (Hidden QGA, Peterborough, $\mathrm{NH}$, USA) measuring volatile species. The signals from the mass spectra of 2, 15, 28, 31, 34, 44, 78 and $94(\mathrm{~m} / z)$ were identified as major contributors from $\mathrm{s}$ evolved gases and volatiles like $\mathrm{H}_{2}$, 
$\mathrm{CH}_{4}, \mathrm{CO}, \mathrm{CH}_{3} \mathrm{OH}, \mathrm{H}_{2} \mathrm{~S}, \mathrm{CO}_{2}$, benzene and phenol. Gaseous species from thermal decomposition of iron-promoted lignin precursors were examined, that is, $\mathrm{HCl}(m / z=36)$ from $\mathrm{FeCl}_{2}$ and $\mathrm{FeCl}_{3}$ samples, $\mathrm{NO}_{2}(m / z=46)$ and $\mathrm{O}_{2}(m / z=32)$ from Fe $\left(\mathrm{NO}_{3}\right)_{3}$ samples and $\mathrm{SO}_{2}(m / z=64)$ and $\mathrm{SO}_{3}(m / z=80)$ from $\mathrm{FeSO}_{4}$ samples.

\subsection{Elemental Analyses}

Carbon $(\mathrm{C})$, hydrogen $(\mathrm{H})$, nitrogen $(\mathrm{N})$ and sulfur $(\mathrm{S})$ contents in raw kraft lignin and thermally treated iron-promoted lignin precursors were measured by a PerkinElmer PE 2400 CHN Elemental Analyzer (Billerica, MA, USA). At least three measurements were conducted for each sample. Chloride was analyzed by dissolving samples in sulfuric acid and by distillation with titration of the distillate according to the Volhard-Charpenter method [14].

\subsection{Characterization}

X-ray powder diffraction (XRD) patterns of thermally treated iron-promoted lignin precursors were obtained using a Rigaku Ultima III X-ray Diffraction System operated at $40 \mathrm{kV}$ and $44 \mathrm{~mA}$ using $\mathrm{Cu}-\mathrm{K} \alpha$ radiation with a wavelength of $15406 \AA$, from $15^{\circ}$ to $80^{\circ}$ at a scan rate of $0.02{ }^{\circ} \mathrm{s}^{-1}$. The Jade powder diffraction analysis software from Materials Data, Inc. (Livermore, CA, USA) was used for both qualitative and quantitative analyses of polycrystalline powder materials. The mean particle size, L, was calculated for the most intense diffraction peaks of $\alpha$-Fe, $\gamma$-Fe and $\mathrm{Fe}_{3} \mathrm{C}$ using the Scherrer formula $[15,16]$. The surface areas of thermally treated iron-promoted lignin precursors were determined using $\mathrm{N}_{2}$ adsorption-desorption (Quantachrome, Autosorb-1). Prior to measurements, all samples were degassed at $300{ }^{\circ} \mathrm{C}$ for $3 \mathrm{~h}$.

The morphology of a thermally treated iron-promoted lignin precursor was investigated using a Scanned Electron Microscope (SEM) (Peabody, MA, USA). All SEM samples were pre-coated with $10 \mathrm{~nm}$ Pt before introduced into the vacuum chamber. The system was operated with an accelerating voltage of $10 \mathrm{kV}$. The particle sizes of thermally treated iron-promoted lignin precursors were examined using a JEOL JEM-100CX II Transmission Electron Microscope (TEM, Peabody, MA, USA) operated at an accelerating voltage of $200 \mathrm{kV}$. All TEM samples were sonicated in ethanol solution for 1 min before transfer to copper grids.

Raman spectra of thermally treated iron-promoted lignin precursors were obtained on a Jobin-Yvon microspectrometer (Edison, NJ, USA) equipped with an excitation laser source emitting at $514 \mathrm{~nm}$ and having an incident power around $1 \mathrm{~mW}$ on a thin surface. Twenty spectra were collected for each sample. Deconvolution of the spectra was performed with the assumption of mixed Gaussian/Lorentzian peaks describing both main D- and G-bands and two minor ones. The D, G and $2 \mathrm{D}$ peaks were fitted with Lorentz functions. The $\mathrm{I}_{\mathrm{D}} / \mathrm{I}_{\mathrm{G}}$ ratio was calculated using the heights of $\mathrm{D}$ and $G$ peak intensities. The crystalline size along the a-axis $\left(\mathrm{L}_{\mathrm{a}}\right)$ was calculated using the Cançado equation [17].

\section{Results and Discussion}

\subsection{Thermal Analyses}

Thermogravimetric analyses (TGA)_FTIR spectra demonstrated that there were many oxygen-containing (carboxylic, carbonyl, acyl, alkoxyl, ketones, esters and ethers, et al.), alkyl and aromatic functional groups in kraft lignin [18]. These functional groups in kraft lignin were broken down or cracked with increasing of temperature during the thermal process. Figure 1 shows TG and DTG curves of four iron salts promoted lignin precursors. Figure 1a shows that solid residues as percentage of starting weights of iron-promoted lignin precursors after decomposition were 52.6\%, $50.9 \%, 41.6 \%$ and $36.6 \%$ for iron salts $\mathrm{FeCl}_{3}, \mathrm{FeCl}_{2}, \mathrm{FeSO}_{4}$ and $\mathrm{Fe}\left(\mathrm{NO}_{3}\right)_{3}$, respectively, which indicates that the catalytic graphitization activity of four iron catalysts on kraft lignin materials was in ascending order $\mathrm{FeCl}_{3}<\mathrm{FeCl}_{2}<\mathrm{FeSO}_{4}<\mathrm{Fe}\left(\mathrm{NO}_{3}\right)_{3}$. 
The thermal decomposition process of iron-promoted lignin precursors can be divided into four stages (Figure 1b). The first stage is characterized by a mass loss because of the evaporation of surface moisture and dehydration of combined moistures from iron-promoted lignin precursors. The second stage corresponded to the de-polymerization of kraft lignin and decomposition of iron species. During the de-polymerization process, the oxygen-containing groups in alkyl side chains of lignin basic units were catalytically decomposed. The mass decreased rapidly due to the breakage of large number of ether and $\mathrm{C}-\mathrm{C}$ bonds connected on phenyl propane units, which generated small-molecule gases and macromolecular condensable volatiles. The maximum rates of these weight losses occurred at the temperatures of $323^{\circ} \mathrm{C}, 300{ }^{\circ} \mathrm{C}, 375^{\circ} \mathrm{C}$ and $237^{\circ} \mathrm{C}$ for $\mathrm{FeCl}_{2^{-}}, \mathrm{FeCl}_{3^{-}}, \mathrm{FeSO}_{4^{-}}$and $\mathrm{Fe}\left(\mathrm{NO}_{3}\right)_{3}$-promoted lignin precursors, respectively. The third mass loss (Figure $1 \mathrm{~b}$ ), corresponding to decomposition of kraft lignin char yielded after the completion of the second stage, indicated that the functional groups of kraft lignin continued to decompose as the temperature increased, which led to the aromatization of kraft lignin char matrix. The fourth mass loss stage was characterized with a further carbonization and graphitization process of chars in a wider temperature range up to $1000{ }^{\circ} \mathrm{C}$, where the mass loss was mainly because of the decomposition of phenols, ether and $\mathrm{C}-\mathrm{H}$ groups of kraft lignin chars, which released out $\mathrm{CO}$ and $\mathrm{H}_{2}$ as main gases.
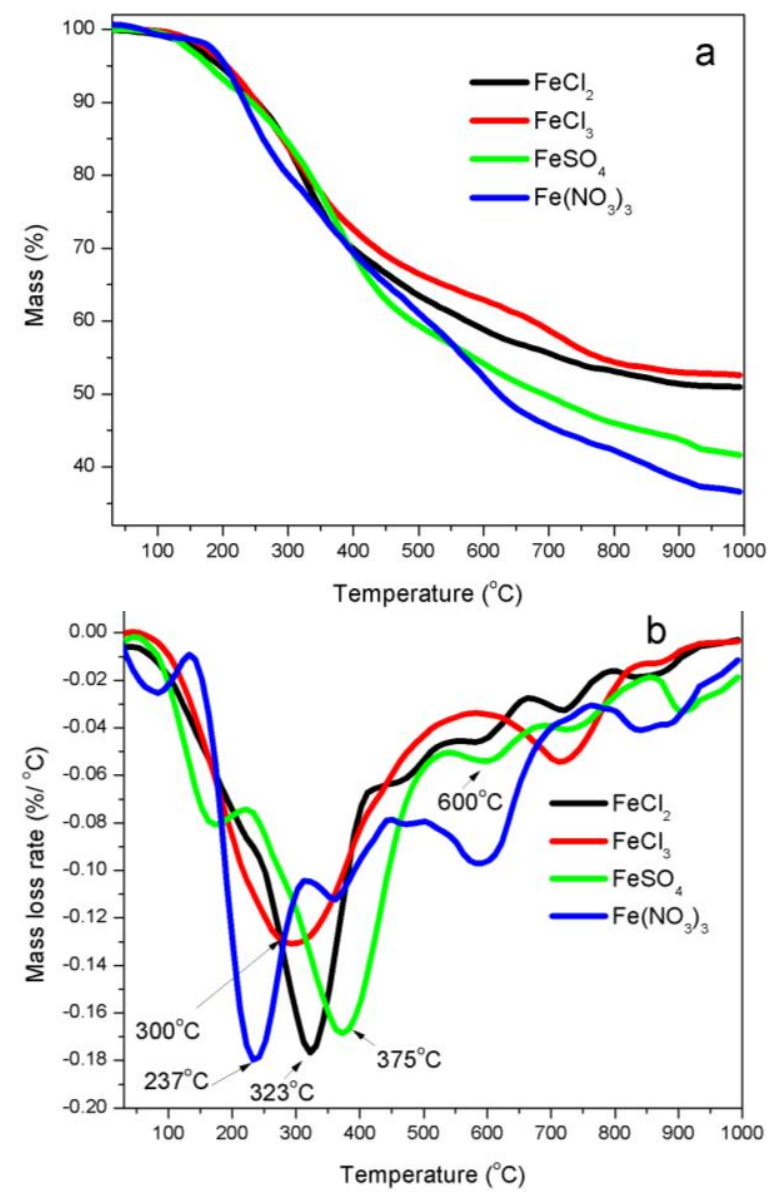

Figure 1. TG (a) and DTG (b) curves of kraft lignin promoted with four iron salts: $\mathrm{FeCl}_{2}, \mathrm{FeCl}_{3}, \mathrm{FeSO}_{4}$ and $\mathrm{Fe}\left(\mathrm{NO}_{3}\right)_{3}$.

Temperature-programmed decomposition (TPD) analyses-Lignin is an across-linked type macromolecule and mostly formed via free radical coupling of three basic hydroxyphenylpropanoid monolignols: coumaryl, coniferyl and sinapyl alcohols [19]. With the aid of catalysts, oxidative agents, or thermal treatment, lignin will break down at positions $1,4,5$ and $\beta$ [18], accompanying the release of incondensable gases like $\mathrm{H}_{2}, \mathrm{CO}_{2}, \mathrm{CO}, \mathrm{CH}_{4}, \mathrm{C}_{2} \mathrm{H}_{6}, \mathrm{C}_{2} \mathrm{H}_{4}, \mathrm{H}_{2} \mathrm{~S}$, trace amounts of gaseous organics 
$\left(\mathrm{CH}_{3} \mathrm{OH}, \mathrm{C}_{6} \mathrm{H}_{6} \mathrm{OH}\right)$ and water vapor or volatile products. In addition, gaseous species are produced from the thermal decomposition of iron salts such as $\mathrm{HCl}$ from $\mathrm{Fe}-\mathrm{Cl}_{2}$ and $\mathrm{Fe}-\mathrm{Cl}_{3}, \mathrm{NO}_{2}$ and $\mathrm{O}_{2}$ from Fe-N and $\mathrm{SO}_{2}$ and $\mathrm{SO}_{3}$ from Fe-S.

Figure 2 shows the evolution curves of release intensities of various gaseous species as a function of heating temperature recorded during the temperature-programmed decomposition of raw kraft lignin and iron-promoted lignin precursors. For raw kraft lignin, the releasing of $\mathrm{H}_{2}$ began at $520{ }^{\circ} \mathrm{C}$ and reached its maximum value at $726^{\circ} \mathrm{C}$. For Fe-N, the releasing of $\mathrm{H}_{2}$ started at $466^{\circ} \mathrm{C}$ and reached its maximum value at $709{ }^{\circ} \mathrm{C} . \mathrm{H}_{2}$ released from $\mathrm{Fe}-\mathrm{S}$ at $466^{\circ} \mathrm{C}$ and reached its maximum value at $790{ }^{\circ} \mathrm{C} . \mathrm{Fe}-\mathrm{Cl}_{3}$ samples began its $\mathrm{H}_{2}$ release at $493{ }^{\circ} \mathrm{C}$ with a maximum value reached at $810^{\circ} \mathrm{C}$, while $\mathrm{Fe}-\mathrm{Cl}_{2}$ samples began its $\mathrm{H}_{2}$ release at $537^{\circ} \mathrm{C}$ with a maximum value reached at $840^{\circ} \mathrm{C}$. More hydrogen was supposed to be produced from the samples with iron catalysts and evolution temperature were supposed to be lower than raw kraft lignin samples. However, the evolution peaks were weaker and flatter and the hydrogen peaks for $\mathrm{FeSO}_{4}, \mathrm{FeCl}_{3}$ and $\mathrm{FeCl}_{2}$ shifted to the higher temperatures. This was caused by the reverse water-gas shift reaction (RWGSR) $\left(\mathrm{CO}_{2}(\mathrm{~g})+\mathrm{H}_{2}(\mathrm{~g})=\mathrm{CO}(\mathrm{g})+\mathrm{H}{ }_{2} \mathrm{O}(\mathrm{g})\right.$ ) . Part of hydrogen from the thermal cracking reaction was consumed through RWGSR since more $\mathrm{CO}_{2}$ was generated from the samples with iron catalysts and iron is very active for the RWGSR under the process conditions. From $\mathrm{H}_{2}$ evolution trends, the catalytic activities of iron catalysts from different precursors were with the following descending order: $\mathrm{Fe}-\mathrm{N}>\mathrm{Fe}-\mathrm{S}>\mathrm{Fe}-\mathrm{Cl}_{3}>\mathrm{Fe}-\mathrm{Cl}_{2}$. Methane was released from the decomposition of kraft lignin between 200 and $1000{ }^{\circ} \mathrm{C}$ under an argon atmosphere (Figure 2b). Methane released below $500^{\circ} \mathrm{C}$ was mainly caused by the fragmentation of kraft lignin side chains. Demethylation of the aromatic methoxy groups $\left(-\mathrm{O}-\mathrm{CH}_{3}\right)$ also contributed to the methane formation in the low temperature range. Methane formation at the temperature above $500{ }^{\circ} \mathrm{C}$ was attributed to the breaking down of aromatic ring skeletons. Methane was observed in two temperature zones for Fe-N lignin samples, that is, the relative small and sharp peak at $250{ }^{\circ} \mathrm{C}$ and a wide and strong methane peak above $400{ }^{\circ} \mathrm{C}$ were observed. The methane evolution peak at a low temperature for Fe-N lignin sample tended to shift to the lower temperature compared to that of raw kraft lignin, that is, the first peak ranged from $455^{\circ} \mathrm{C}$ to $240{ }^{\circ} \mathrm{C}$ and the high temperature methane evolution peak area was increased significantly. This might be because of the promotion effect of iron on lignin decomposition. The formation of methane significantly increased above $400{ }^{\circ} \mathrm{C}$ for Fe- $\mathrm{N}$ samples, possibly because of iron components catalytically cracking down aromatic ring skeletons in kraft lignin. Methane evolution profiles of $\mathrm{FeSO}_{4}, \mathrm{FeCl}_{2}$ and $\mathrm{FeCl}_{3}$ samples were similar to that of raw lignin but the methane evolution peaks of $\mathrm{FeCl}_{2}$ and $\mathrm{FeCl}_{3}$ samples at the low temperature shifted to lower temperatures compared to Fe-N sample, the first peak ranged from $455{ }^{\circ} \mathrm{C}$ to $250{ }^{\circ} \mathrm{C}$ for $\mathrm{FeCl}_{3}$ samples and $455^{\circ} \mathrm{C}$ to $350{ }^{\circ} \mathrm{C}$ for $\mathrm{FeCl}_{2}$ samples. These shifts in temperatures attributed to the catalytic decomposition activity of iron ions $\left(\mathrm{Fe}^{3+}\right.$ and $\left.\mathrm{Fe}^{2+}\right)$ to methoxy groups $\left(-\mathrm{O}-\mathrm{CH}_{3}\right)$. No significant difference in the temperature shift was observed for $\mathrm{FeSO}_{4}$ samples.

Two CO evolution peaks were observed for raw kraft lignin samples under an argon atmosphere. The $\mathrm{CO}$ evolution peak at a low temperature was $418{ }^{\circ} \mathrm{C}$, which was mainly contributed to the decomposition of carboxyl $(\mathrm{C}=\mathrm{O})$ groups and the $\mathrm{CO}$ evolution peak centered at $770{ }^{\circ} \mathrm{C}$ was attributed to the cracking down of carbonyl $(\mathrm{C}-\mathrm{O}-\mathrm{C})$. The $\mathrm{CO}$ formation of Fe- $\mathrm{N}$ lignin samples had three temperature zones, that is, a sharp peak centered at $237{ }^{\circ} \mathrm{C}$, a wide flat peak at $640{ }^{\circ} \mathrm{C}$ and a strong $\mathrm{CO}$ evolution peak at $900{ }^{\circ} \mathrm{C}$ (Figure 2c). The $\mathrm{CO}$ evolution at $237{ }^{\circ} \mathrm{C}$ was contributed by the decarbonylation reaction of the $\mathrm{C}_{3}$ side-chains of lignin, which was catalytically decomposed at low temperature by $\mathrm{Fe}^{3+}$. The $\mathrm{CO}$ peak at $640{ }^{\circ} \mathrm{C}$ was because of the cracking down of carbonyl (C-O-C), while the $\mathrm{CO}$ peak at $900{ }^{\circ} \mathrm{C}$ was most likely because of the thermal cracking down of char residues. The $\mathrm{CO}$ evolution profiles of $\mathrm{FeSO}_{4}, \mathrm{FeCl}_{2}$ and $\mathrm{FeCl}_{3}$ samples were similar to the ones of raw lignin but the $\mathrm{CO}$ evolution peak of $\mathrm{FeCl}_{3}$ samples at the low temperature shifted to the lower temperature region, which was because of the influence of the catalytic activity of iron ions $\left(\mathrm{Fe}^{3+}\right)$ and the decarbonylation reaction. No significant difference in $\mathrm{CO}$ formation was observed for $\mathrm{FeSO}_{4}$ and $\mathrm{FeCl}_{2}$ samples. 
$\mathrm{CO}_{2}$ released during lignin decomposition because of the decomposition of carboxyl and ester groups of kraft lignin. Two significant peaks presented during the decomposition of kraft lignin under an argon atmosphere (Figure $2 \mathrm{~d}$ ). Carboxyl (-COO-) was considered to be predominantly responsible for the peak at the low temperature of $407^{\circ} \mathrm{C}$. The $\mathrm{CO}_{2}$ evolution at the high temperature of $642^{\circ} \mathrm{C}$ was assigned to ester groups when the thermal process was under an inert atmosphere.

$\mathrm{CO}_{2}$ was also observed in three temperature zones for Fe-N lignin samples, that is, a sharp peak centered at $237{ }^{\circ} \mathrm{C}$, a wide strong peak at $630{ }^{\circ} \mathrm{C}$ and a weak flat evolution peak at $870{ }^{\circ} \mathrm{C}$. The formation of $\mathrm{CO}_{2}$ at $237^{\circ} \mathrm{C}$ was contributed by decomposition of carboxyl (-COO-) and $\mathrm{COOH}$ groups in lignin which were catalytically decomposed by $\mathrm{Fe}^{3+}$ at a lower temperature. The $\mathrm{CO}_{2}$ peak at $630{ }^{\circ} \mathrm{C}$ was because of the cracking down of ester groups, while the $\mathrm{CO}_{2}$ peak at $900{ }^{\circ} \mathrm{C}$ was assigned to the thermal cracking down of char residues. The $\mathrm{CO}_{2}$ evolution profiles of $\mathrm{FeSO}_{4}, \mathrm{FeCl}_{2}$ and $\mathrm{FeCl}_{3}$ samples were similar to the one of raw lignin but the $\mathrm{CO}_{2}$ evolution peak of $\mathrm{FeCl}_{3}$ samples shifted to the lower temperature region because of the influence of the catalytic activity of iron ions $\left(\mathrm{Fe}^{3+}\right)$ to the decarbonylation reaction.

The formation of phenols started with the dehydration of $-\mathrm{OH}$ groups in alkyl side chains of lignin basic units, followed by the cleavage of ether bonds between these units. The profile of phenols from the decomposition of kraft lignin under an argon atmosphere (Figure 2e) showed a phenol peak at $473{ }^{\circ} \mathrm{C}$. Phenol formation peaks shifted to the low temperature region for Fe-kraft lignin samples.

The plot of the evolution of a typical aromatic compound of benzene from the thermal decomposition of kraft lignin samples (Figure 2f) showed that the evolution of benzene from the decomposition of kraft lignin under an inert atmosphere was detected over a wide temperature range from 528 to $938^{\circ} \mathrm{C}$, with a peak temperature at $697^{\circ} \mathrm{C}$. The formation of benzene in Fe-N samples was detected over two temperature zones: a weak flat peak in the temperature range from 220 to $380^{\circ} \mathrm{C}$ and a strong wide peak in the temperature range from 510 to $1000^{\circ} \mathrm{C}$ with the peak centered at $778{ }^{\circ} \mathrm{C}$. Benzene was observed to be generated at a steady increasing level for the Fe-S sample when the heating temperature was above $500{ }^{\circ} \mathrm{C}$. The evolution of benzene in $\mathrm{Fe}-\mathrm{Cl}_{3}$ samples was detected over $520^{\circ} \mathrm{C}$ with a wide flat peak in the temperature range from 520 to $1000{ }^{\circ} \mathrm{C}$. Benzene was the only gas observed released from $\mathrm{Fe}-\mathrm{Cl}_{2}$ samples at temperatures above $720{ }^{\circ} \mathrm{C}$.

The evolution of methanol from raw kraft lignin samples heated under an argon flow was detected over a temperature range from 351 to $695{ }^{\circ} \mathrm{C}$ with a peak temperature at $494{ }^{\circ} \mathrm{C}$ (Figure $2 \mathrm{~g}$ ). The evolution profiles of methanol from Fe-lignin samples were significantly different than those of raw kraft lignin in intensity and temperature range. Methanol evolution peaks of Fe-lignin samples all shifted to the low temperature region and also had weaker intensity. This could be because the effect of the catalytic activity of iron and to the decomposition of aromatic methoxy groups $\left(\mathrm{CH}_{3} \mathrm{O}-\right)$ and aliphatic $-\mathrm{CH}_{2} \mathrm{OH}$ group in lignin. Light hydrocarbons (mainly methane) were the preferred products other than methanol for iron-promoted samples (Figure $2 \mathrm{~g}$ ).

When lignin was de-polymerized, sulfur can be present in many components of the gas phase, such as dimethylsulfide, carbonyl sulfide and hydrogen sulfide $\left(\mathrm{H}_{2} \mathrm{~S}\right)$. The $\mathrm{H}_{2} \mathrm{~S}$ evolution was monitored during the decomposition of kraft lignin samples under an argon atmosphere (Figure $2 \mathrm{~h}$ ). $\mathrm{H}_{2} \mathrm{~S}$ formed in the temperature range from 210 to $646^{\circ} \mathrm{C}$, with a maximum value reached at $341^{\circ} \mathrm{C}$. $\mathrm{H}_{2} \mathrm{~S}$ formation profiles in Fe-lignin samples were different with these in raw kraft lignin samples in terms of intensity and temperature range. The $\mathrm{H}_{2} \mathrm{~S}$ evolution peaks of Fe-lignin samples were all in low intensity range. $\mathrm{No}_{2} \mathrm{~S}$ gas was detected in $\mathrm{Fe}-\mathrm{N}$ samples. The $\mathrm{H}_{2} \mathrm{~S}$ peak in Fe-S samples shifted to a high temperature zone of $350-650{ }^{\circ} \mathrm{C}$ with its peak temperature at $470{ }^{\circ} \mathrm{C} . \mathrm{H}_{2} \mathrm{~S}$ released as a flat peak between $308{ }^{\circ} \mathrm{C}$ and $690^{\circ} \mathrm{C}$ in $\mathrm{Fe}-\mathrm{Cl}_{3}$ samples, while a wide flat $\mathrm{H}_{2} \mathrm{~S}$ evolution peak in a temperature range of $268-880^{\circ} \mathrm{C}$ was observed in $\mathrm{Fe}^{-\mathrm{Cl}_{2}}$ samples. The sulfur content in kraft lignin samples seems to be absorbed completely (Fe-N) or partially ( $\mathrm{Fe}-\mathrm{S}, \mathrm{Fe}-\mathrm{Cl}_{3}$ and $\mathrm{Fe}-\mathrm{Cl}_{2}$ ) by iron components during the thermal decomposition. 

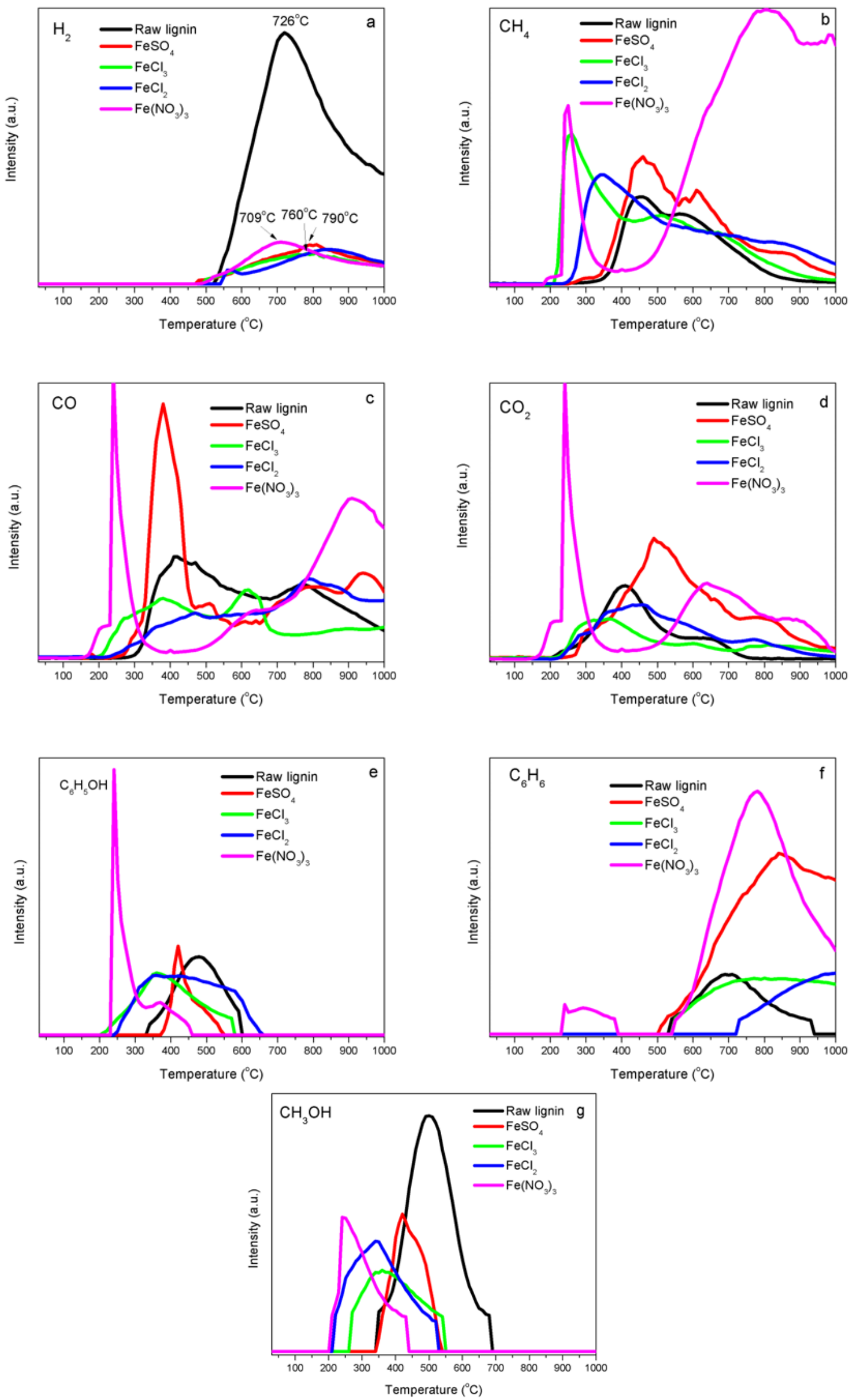

Figure 2. Cont. 

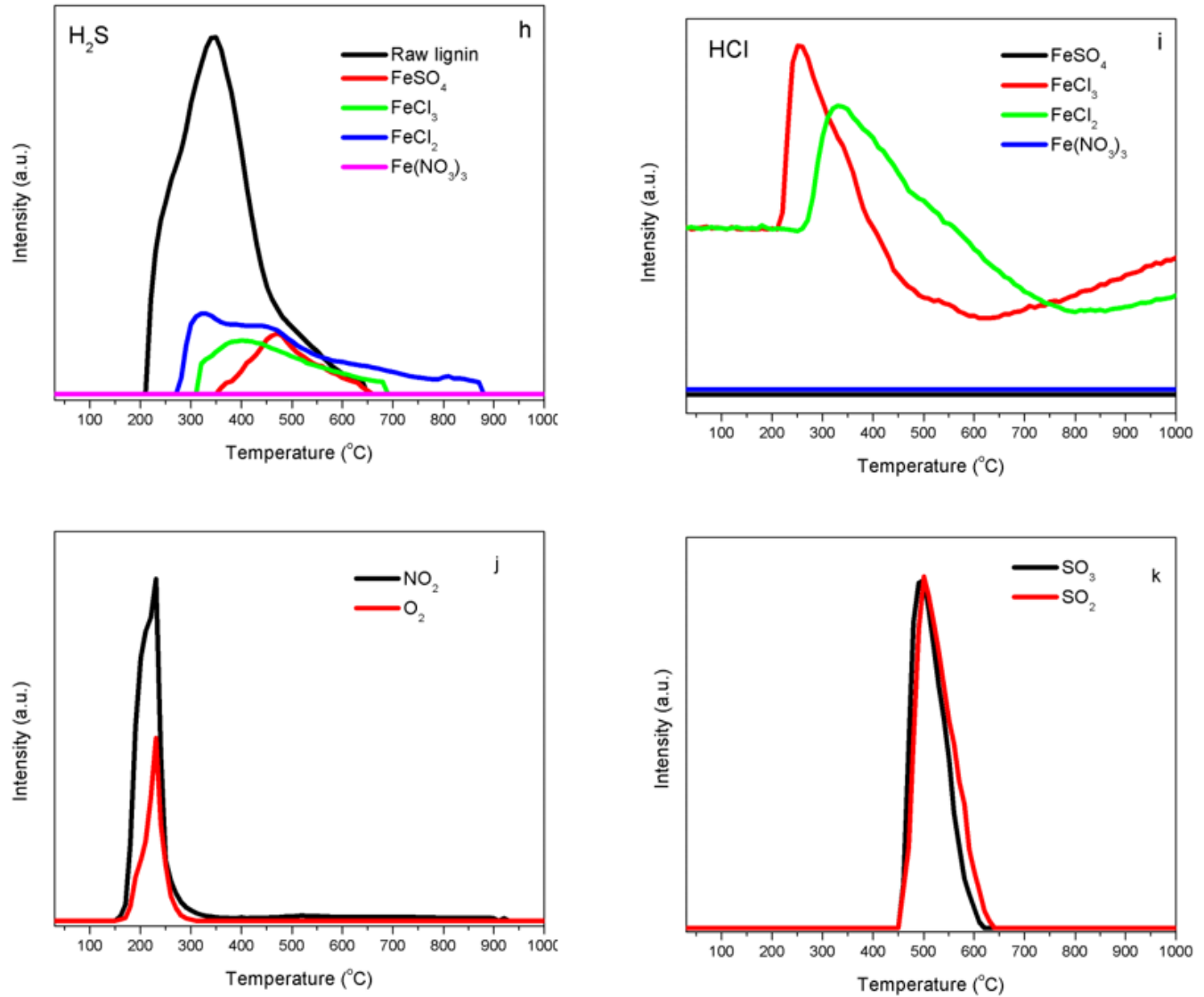

Figure 2. Evolution of gases and volatiles from thermally treated kraft lignin samples promoted with different iron compounds $\left(\mathrm{FeCl}_{2}, \mathrm{FeCl}_{3}, \mathrm{FeSO}_{4}\right.$ and $\left.\mathrm{Fe}\left(\mathrm{NO}_{3}\right)_{3}\right)$ : (a) $\mathrm{H}_{2}$, (b) $\mathrm{CH}_{4}$, (c) $\mathrm{CO}$, (d) $\mathrm{CO}_{2}$, (e) phenol, (f) benzene, (g) $\mathrm{CH}_{3} \mathrm{OH}$, (h) $\mathrm{H}_{2} \mathrm{~S}$, (i) $\mathrm{HCl}$ (from $\mathrm{FeCl}_{2}, \mathrm{FeCl}_{3}$ ), (j) $\mathrm{NO}_{2}$ and $\mathrm{O}_{2}$ (from $\mathrm{Fe}$ $\left.\left(\mathrm{NO}_{3}\right)_{3}\right),(\mathbf{k}) \mathrm{SO}_{2}$ and $\mathrm{SO}_{3}$ (from $\mathrm{FeSO}_{4}$ ).

There were two formation zones of $\mathrm{HCl}$ released as a volatile from both $\mathrm{FeCl}_{3}$-and $\mathrm{FeCl}_{2}$-promoted kraft lignin samples. $\mathrm{Fe}^{-\mathrm{Cl}_{3}}$ samples had a $\mathrm{HCl}$ evolution peak centered at $256.6^{\circ} \mathrm{C}$ within a low temperature range from 205 to $597^{\circ} \mathrm{C}$. The thermal decomposition of hexahydrate iron(III) chloride produced iron(III) oxide, hydrogen chloride and water. These reactions occurred at a temperature above $250{ }^{\circ} \mathrm{C}$.

$$
\begin{gathered}
\mathrm{FeCl}_{3}+\mathrm{H}_{2} \mathrm{O} \rightarrow \mathrm{FeOCl}+2 \mathrm{HCl} \\
2 \mathrm{FeCl}_{3}+3 \mathrm{H}_{2} \mathrm{O} \rightarrow \mathrm{Fe}_{2} \mathrm{O}_{3}+6 \mathrm{HCl}
\end{gathered}
$$

$\mathrm{HCl}$ began to free from the samples at a high temperature of $623.3^{\circ} \mathrm{C}$ due to the desorption of surface $\mathrm{Cl}$ atoms with the assistance of hydrogen atoms: $\mathrm{H} \cdot+\mathrm{Cl} \cdot \rightarrow \mathrm{HCl}$.

For the $\mathrm{Fe}-\mathrm{Cl}_{2}$ sample, $\mathrm{HCl}$ was formed at higher temperature compared to the $\mathrm{Fe}_{-} \mathrm{Cl}_{3}$ sample, the $\mathrm{HCl}$ peak attributed to the hydrolysis of $\mathrm{FeCl}_{2}$ was centered at $333^{\circ} \mathrm{C}$ with a temperature range of $249-793{ }^{\circ} \mathrm{C}$ :

$$
\mathrm{FeCl}_{2}+\mathrm{H}_{2} \mathrm{O} \rightarrow \mathrm{FeO}+2 \mathrm{HCl}
$$

the formation of $\mathrm{HCl}$ started at a high temperature of $798.8^{\circ} \mathrm{C}$. The formation peaks were contributed by the desorption of surface chlorine with the assistance of hydrogen atoms: $\mathrm{H} \cdot+\mathrm{Cl} \cdot \rightarrow \mathrm{HCl}$.

Figure 2j shows the trends of $\mathrm{NO}_{2}$ and $\mathrm{O}_{2}$ during temperature-programmed decomposition of iron nitrate-promoted lignin samples. $\mathrm{NO}_{2}$ and $\mathrm{O}_{2}$ appeared between 160 and $350{ }^{\circ} \mathrm{C}$ with a peak temperature of $230^{\circ} \mathrm{C}$. This indicated that the thermal decomposition of iron(III) nitrate produced iron(III) oxide, nitric oxide and oxygen [20]: 


$$
4 \mathrm{Fe}\left(\mathrm{NO}_{3}\right)_{3} \rightarrow 2 \mathrm{Fe}_{2} \mathrm{O}_{3}+12 \mathrm{NO}_{2}+3 \mathrm{O}_{2}
$$

Figure $2 \mathrm{k}$ shows the trends of $\mathrm{SO}_{2}$ and $\mathrm{SO}_{3}$ during temperature-programmed decomposition of $\mathrm{FeSO}_{4}$-promoted lignin samples. The anhydrous $\mathrm{FeSO}_{4}$ released sulfur dioxide and white fumes of sulfur trioxide, which left a reddish-brown iron(III) oxide [21]:

$$
2 \mathrm{FeSO}_{4} \rightarrow \mathrm{Fe}_{2} \mathrm{O}_{3}+\mathrm{SO}_{2}+\mathrm{SO}_{3}
$$

The decomposition of sulfate initiated around $450{ }^{\circ} \mathrm{C}$, formed a sharp peak at $500{ }^{\circ} \mathrm{C}$.

\subsection{Iron Catalyst Effects}

Product distributions-Table 1 summarizes the yields of three phases, gas, liquid (tars, condensable vapors, etc.) and solid (carbon and metal), produced during the catalytic graphitization of Fe-kraft lignin samples at $1000{ }^{\circ} \mathrm{C}$ under an argon atmosphere. The yields of solid carbon residues were $35.3 \%, 35.0 \%, 33.6 \%$ and $31.3 \%$ for $\mathrm{Fe}^{-} \mathrm{Cl}_{2}, \mathrm{Fe}_{-} \mathrm{Cl}_{3}$, $\mathrm{Fe}-\mathrm{S}$ and $\mathrm{Fe}-\mathrm{N}$ as iron sources, respectively. Thermally treated Fe-lignin samples with $\mathrm{Fe}-\mathrm{Cl}_{2}$ and $\mathrm{Fe}-\mathrm{Cl}_{3}$ as iron sources had lower conversion rates than one with Fe-N.

Table 1. Effects of iron sources on products weight percentage distribution of catalytic decomposition of kraft lignin at the temperature of $1000^{\circ} \mathrm{C}$ for $1 \mathrm{~h}$.

\begin{tabular}{cccc}
\hline Fe Resources & Solid Carbon & Liquid & Gas \\
\hline $\mathrm{Fe}-\mathrm{S}$ & 33.6 & 19.5 & 46.9 \\
$\mathrm{Fe}-\mathrm{Cl}$ & 35.0 & 20.2 & 44.8 \\
$\mathrm{Fe}_{3}-\mathrm{Cl}_{2}$ & 35.3 & 19.7 & 45 \\
$\mathrm{Fe}-\mathrm{N}$ & 31.3 & 18 & 50.7 \\
\hline
\end{tabular}

\subsection{Solid Products Characterization}

Elemental analyses-Table 2 summarizes the results of $\mathrm{C}-\mathrm{H}-\mathrm{N}-\mathrm{S}-\mathrm{Cl}$ elemental analyses performed for raw kraft lignin and thermally treated Fe-lignin samples. The weight contents of $\mathrm{C}, \mathrm{H}, \mathrm{N}$ and $\mathrm{S}$ in raw kraft lignin samples were $65.2 \%, 6.1 \%, 0.1 \%$ and $0.8 \%$, respectively and no $\mathrm{Cl}$ was detected. For thermally treated Fe-lignin samples, Fe-N samples had the highest carbon content of $98.5 \mathrm{wt} \%$, followed by Fe-S of $97.3 \%, \mathrm{Fe}^{-\mathrm{Cl}_{3}}$ of $95.7 \%$ and $\mathrm{Fe}^{-\mathrm{Cl}_{2}}$ of $95.0 \%$; hydrogen contents were $0.4 \%, 0.6 \%, 0.8 \%$ and $0.1 \%$ for $\mathrm{Fe}-\mathrm{S}, \mathrm{Fe}-\mathrm{Cl}_{3}, \mathrm{Fe}^{-\mathrm{Cl}_{2}}$ and $\mathrm{Fe}-\mathrm{N}$ samples, respectively. No nitrogen was found in thermally treated Fe-lignin samples. Sulfur contents in thermally treated Fe-lignin samples were $0.7 \%, 0.4 \%, 0.2 \%$ and $1.2 \%$ for $\mathrm{Fe}-\mathrm{S}, \mathrm{Fe}-\mathrm{Cl}_{3}, \mathrm{Fe}_{-} \mathrm{Cl}_{2}$ and $\mathrm{Fe}-\mathrm{N}$ samples, respectively. The mass contents of chlorine detected in both $\mathrm{Fe}-\mathrm{Cl}_{2}$ and $\mathrm{Fe}_{-}-\mathrm{Cl}_{3}$ samples were $0.8 \%$ and $0.5 \%$, respectively.

Table 2. Weight percentage values of elemental analyses of raw kraft lignin and thermally treated Fe-lignin samples with different iron catalysts under argon atmosphere at $1000^{\circ} \mathrm{C}$ for $1 \mathrm{~h}$.

\begin{tabular}{cccccc}
\hline Samples & $\mathbf{C}$ & $\mathbf{H}$ & $\mathbf{N}$ & $\mathbf{S}$ & $\mathbf{C l}$ \\
\hline Raw kraft lignin & $65.2 \pm 0.2$ & $6.1 \pm 0.2$ & $0.1 \pm 0.05$ & $0.8 \pm 0.2$ & N/A \\
Fe-S & $97.3 \pm 0.5$ & $0.4 \pm 0.2$ & N/A & $0.7 \pm 0.1$ & N/A \\
$\mathrm{Fe}-C l_{3}$ & $95.7 \pm 0.9$ & $0.6 \pm 0.3$ & N/A & $0.4 \pm 0.1$ & $0.5 \pm 0.3$ \\
$\mathrm{Fe}^{-C l} l_{2}$ & $95.0 \pm 0.7$ & $0.8 \pm 0.2$ & N/A & $0.2 \pm 0.2$ & $0.8 \pm 0.4$ \\
$\mathrm{Fe}-\mathrm{N}$ & $98.5 \pm 0.5$ & $0.1 \pm 0.05$ & N/A & $1.2 \pm 0.3$ & N/A \\
\hline
\end{tabular}

Surface area-Table 3 summarizes BET surface areas measured on samples promoted with different iron compounds. The surface area value was in the range of $55-108 \mathrm{~m}^{2} / \mathrm{g}$ and ordered as $\mathrm{Fe}-\mathrm{N}>\mathrm{Fe}-\mathrm{S}>\mathrm{Fe}-\mathrm{Cl}_{3}>\mathrm{Fe}-\mathrm{Cl}_{2}$ from high to low, that is, the sample prepared from iron nitrate had the highest surface area among four sample groups evaluated. 
Table 3. Surface area $\left(\mathrm{S}_{\mathrm{g}}\right)$ of carbon-based nanomaterials from kraft lignin promoted with different iron catalysts.

\begin{tabular}{cc}
\hline Samples & $\mathbf{S}_{\mathbf{g}}\left(\mathbf{m}^{\mathbf{2}} \mathbf{g}^{-\mathbf{1}}\right)$ \\
\hline $\mathrm{Fe}-\mathrm{N}$ & 108 \\
$\mathrm{Fe}-\mathrm{Cl}_{2}$ & 55 \\
$\mathrm{Fe}_{2} \mathrm{Cl}_{3}$ & 60 \\
$\mathrm{Fe}-\mathrm{S}$ & 79 \\
\hline
\end{tabular}

$X R D$-Figure 3 shows the XRD patterns of thermally treated Fe-lignin samples prepared using $\mathrm{Fe}-\mathrm{N}, \mathrm{Fe}-\mathrm{S}, \mathrm{Fe}-\mathrm{Cl}_{2}$ and $\mathrm{Fe}-\mathrm{Cl}_{3}$ compounds. The symbols of ${ }^{*}, \mathrm{x}$ and o represent the characteristic diffraction peaks of metallic $\alpha$-Fe (JCPDS, No. 87-0722), $\gamma$-Fe (JCPDS, No. 89-3939) and $\mathrm{Fe}_{3} \mathrm{C}$ (JCPDS, No. 89-2867), respectively. The diffraction peaks at $26.5^{\circ}$ indicated the (002) plane of graphitic carbon. Both thermally treated $\mathrm{Fe}$-lignin samples prepared using $\mathrm{Fe}_{-} \mathrm{Cl}_{2}$ and $\mathrm{Fe}-\mathrm{Cl}_{3}$ exhibited sharp and narrow peaks of metallic iron (mainly $\alpha$-Fe and $\gamma$-Fe). Thermally treated Fe-lignin samples prepared using Fe-S showed both metallic iron peaks $\left(\alpha-\mathrm{Fe}\right.$ and $\gamma$-Fe) and small and broad peaks of iron carbide $\left(\mathrm{Fe}_{3} \mathrm{C}\right)$. Thermally treated Fe-lignin samples prepared using Fe-N showed weak and broad peaks of metallic iron (mainly $\gamma-\mathrm{Fe}$ ) and iron carbide $\left(\mathrm{Fe}_{3} \mathrm{C}\right)$, which indicated the presence of smaller Fe particles in Fe-N prepared samples compared to $\mathrm{Fe}-\mathrm{Cl}_{2}$ and $\mathrm{Fe}-\mathrm{Cl}_{3}$ prepared samples. The short-broad diffraction peaks observed in Fe-N prepared samples suggested good dispersion of iron species in the product. The sharper diffraction peaks of $\mathrm{Fe}-\mathrm{Cl}_{2}$ and $\mathrm{Fe}-\mathrm{Cl}_{3}$ prepared samples implied a growth in the crystallite size of metallic irons or iron carbide $\left(\mathrm{Fe}_{3} \mathrm{C}\right)$.

The mean particle size was calculated for the most intense diffraction peaks of $\alpha-\mathrm{Fe}, \gamma$-Fe and $\mathrm{Fe}_{3} \mathrm{C}$ using the Scherrer formula [15]. Only $\alpha$-Fe and $\gamma$-Fe were detected in $\mathrm{Fe}^{-} \mathrm{Cl}_{2}$ and $\mathrm{Fe}-\mathrm{Cl}_{3}$ prepared samples, while $\alpha$-Fe, $\gamma$-Fe and $\mathrm{Fe}_{3} \mathrm{C}$ were observed in $\mathrm{Fe}-\mathrm{S}$ and $\mathrm{Fe}-\mathrm{N}$ prepared samples. The mean sizes of $\alpha$-Fe nanoparticles were 79.6, 40.2, 59.1 and $18.5 \mathrm{~nm}$ for $\mathrm{Fe}_{-} \mathrm{Cl}_{2}, \mathrm{Fe}-\mathrm{Cl}_{3}, \mathrm{Fe}-\mathrm{S}$ and $\mathrm{Fe}-\mathrm{N}$ prepared samples, respectively; while the $\gamma$-Fe grain sizes averaged 15.3, 30.2, 21.9 and $9.8 \mathrm{~nm}$, respectively. The mean sizes of $\mathrm{Fe}_{3} \mathrm{C}$ nanoparticles were 22.5 and $19.7 \mathrm{~nm}$ for Fe-S and Fe-N prepared samples, respectively.

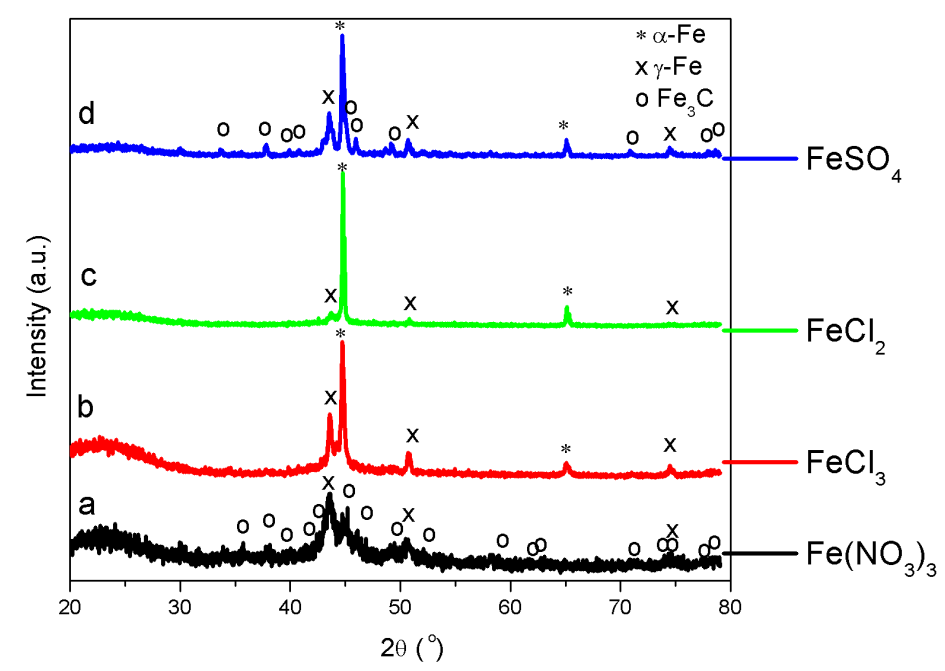

Figure 3. XRD patterns of Fe-lignin samples prepared using iron nitrate (a), iron(III) chloride (b), iron(II) chloride (c) and iron(II) sulfate (d) compounds.

Raman-Figure 4 is the Raman spectra of thermally treated Fe-lignin samples prepared with four iron sources at $1000^{\circ} \mathrm{C}$, displaying a characteristic graphite G-band at $1580 \mathrm{~cm}^{-1}$, D-band at $1350 \mathrm{~cm}^{-1}$ and 2D-band at $2710 \mathrm{~cm}^{-1}$, respectively. The Raman spectra were fitted by Lorentz function to obtain values of $I_{D}, I_{G}, I_{D+G}$ and $I_{2 D}$ values were calculated through fitting Raman spectra with the Lorentz function. The intensity ratios of the $\mathrm{D}$ to $\mathrm{G}$ band $\left(\mathrm{I}_{\mathrm{D}} / \mathrm{I}_{\mathrm{G}}\right)$ of $\mathrm{Fe}-\mathrm{Cl}_{2}$ and $\mathrm{Fe}^{-} \mathrm{Cl}_{3}$ prepared samples were 
1.56 and 1.57, respectively, which were higher than those prepared with Fe-Sand Fe-N of values 1.43 and 1.29, respectively. These results suggested that thermally treated Fe-lignin samples prepared from iron sources of $\mathrm{Fe}-\mathrm{Cl}_{2}$ and $\mathrm{Fe}-\mathrm{Cl}_{3}$ had higher disorder structures, while Fe-N prepared samples had a higher graphitic degree.

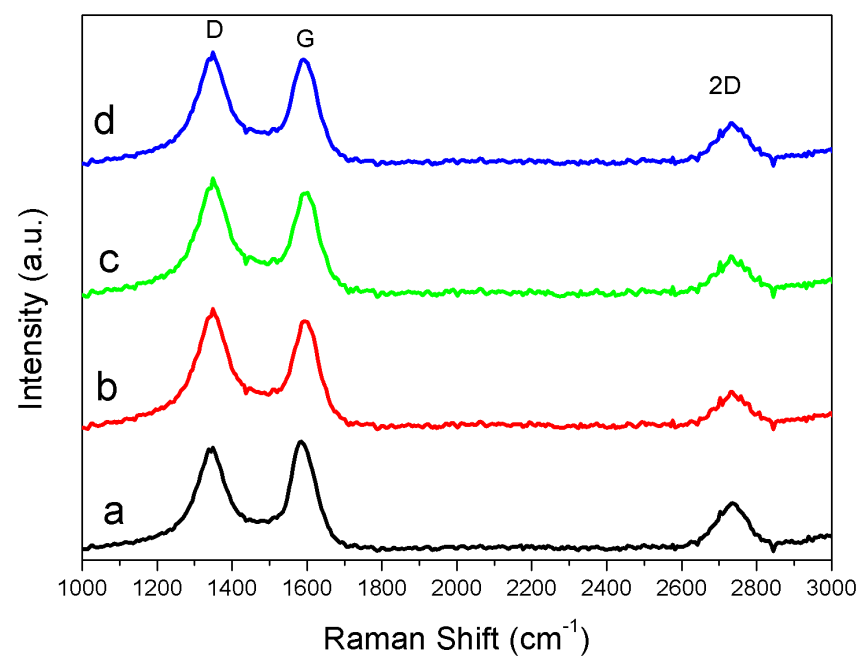

Figure 4. Raman spectra of thermally treated Fe-lignin samples prepared using different iron sources as catalysts: $\mathrm{Fe}-\mathrm{N}(\mathbf{a}), \mathrm{Fe}^{-} \mathrm{Cl}_{3}(\mathbf{b}), \mathrm{Fe}_{-} \mathrm{Cl}_{2}$ (c) and $\mathrm{Fe}-\mathrm{S}(\mathbf{d})$.

Scanning electron microscope (SEM) - The SEM images (Figure 5) show typical morphologies observed on thermally treated Fe-lignin samples prepared with four iron sources of $\mathrm{Fe}-\mathrm{N}, \mathrm{Fe}-\mathrm{S}, \mathrm{Fe}-\mathrm{Cl}_{2}$ and $\mathrm{Fe}-\mathrm{Cl}_{3}$. The morphologies of $\mathrm{Fe}-\mathrm{Cl}_{2}, \mathrm{Fe}-\mathrm{Cl}_{3}$ and $\mathrm{Fe}-\mathrm{S}$ prepared samples were significantly different from ones of Fe-N samples. The $\mathrm{Fe}-\mathrm{Cl}_{2}, \mathrm{Fe}-\mathrm{Cl}_{3}$ and $\mathrm{Fe}-\mathrm{S}$ prepared samples had large pieces of solid grains. At the low magnification, the surfaces of $\mathrm{Fe}-\mathrm{Cl}_{2}, \mathrm{FeCl}_{3}$ and $\mathrm{Fe}-\mathrm{O}$ prepared samples were smooth and clean and with some gas channels (holes). At the high magnification, a layer of fine particle structures was observed over the surface of these samples. The morphologies of $\mathrm{Fe}-\mathrm{Cl}_{2}, \mathrm{Fe}-\mathrm{Cl}_{3}$ and Fe-S prepared samples looked more like raw lignin samples thermally treated at $1000{ }^{\circ} \mathrm{C}$ without any catalyst added.

The SEM images of Fe-N prepared samples showed a very fine powder structure, that is, small particles at the low magnification. At the high magnification, these particles were spherical nanoparticles with a relatively uniform particle size ranging between 5 and $10 \mathrm{~nm}$. XRD results proved that these nanoparticles were composed of $\alpha-\mathrm{Fe}, \gamma-\mathrm{Fe}$, iron carbide and graphene structures.

High resolution transmission electron microscopy (HRTEM)_Figure 6 displays HRTEM images of thermally treated Fe-lignin samples. The dark spots in HRTEM images represented iron species dispersed in carbon-based materials. The nanoparticles in Fe-N prepared samples had core-shell structures with the diameter of core nanospheres in 3-5 nm range. The carbon shells exhibited ordered graphene plane structures. These Fe-core and graphene structure shelled nanoparticles homogenously embedded in the amorphous carbon framework (gray matrix). High-magnification TEM images indicated that these core-shell structures contained onion-like graphitic carbon nanostructures. The morphology of Fe-lignin samples prepared with iron chlorides and iron(II) sulfate was much different compared with Fe-N prepared samples. When iron chlorides and iron(II) sulfate were used as catalyst sources, serious agglomeration of iron particles occurred and the particle size reached as large as 50-100 $\mathrm{nm}$ in diameters. These iron nanoparticles unevenly distributed in the amorphous carbon matrix contained non-uniformly shaped solid iron crystallites. Most of iron-core nanoparticles in $\mathrm{Fe}-\mathrm{Cl}_{2}, \mathrm{FeCl}_{3}$ and Fe-S prepared Fe-lignin samples were shelled with disordered amorphous carbon structures. This was presumably the seriously sintering of metallic iron particles because XRD results revealed that larger crystallite sizes of iron particles observed in $\mathrm{Fe}-\mathrm{Cl}_{2}, \mathrm{Fe}-\mathrm{Cl}_{3}$ and Fe-S prepared Fe-lignin samples than ones prepared with Fe-N. These results disclosed that uniformly dispersed 
smaller iron nanoparticles were beneficial for obtaining a highly performed iron catalyst towards the graphitization to kraft lignin, while agglomerated larger iron nanoparticles deteriorated the catalytic performance of irons as a catalyst. Variation in crystallite size of iron species with different iron catalysts was observed in the order of $\mathrm{Fe}^{-\mathrm{Cl}_{2}}>\mathrm{Fe}-\mathrm{Cl}_{3}>\mathrm{Fe}-\mathrm{S}>\mathrm{Fe}-\mathrm{N}$.

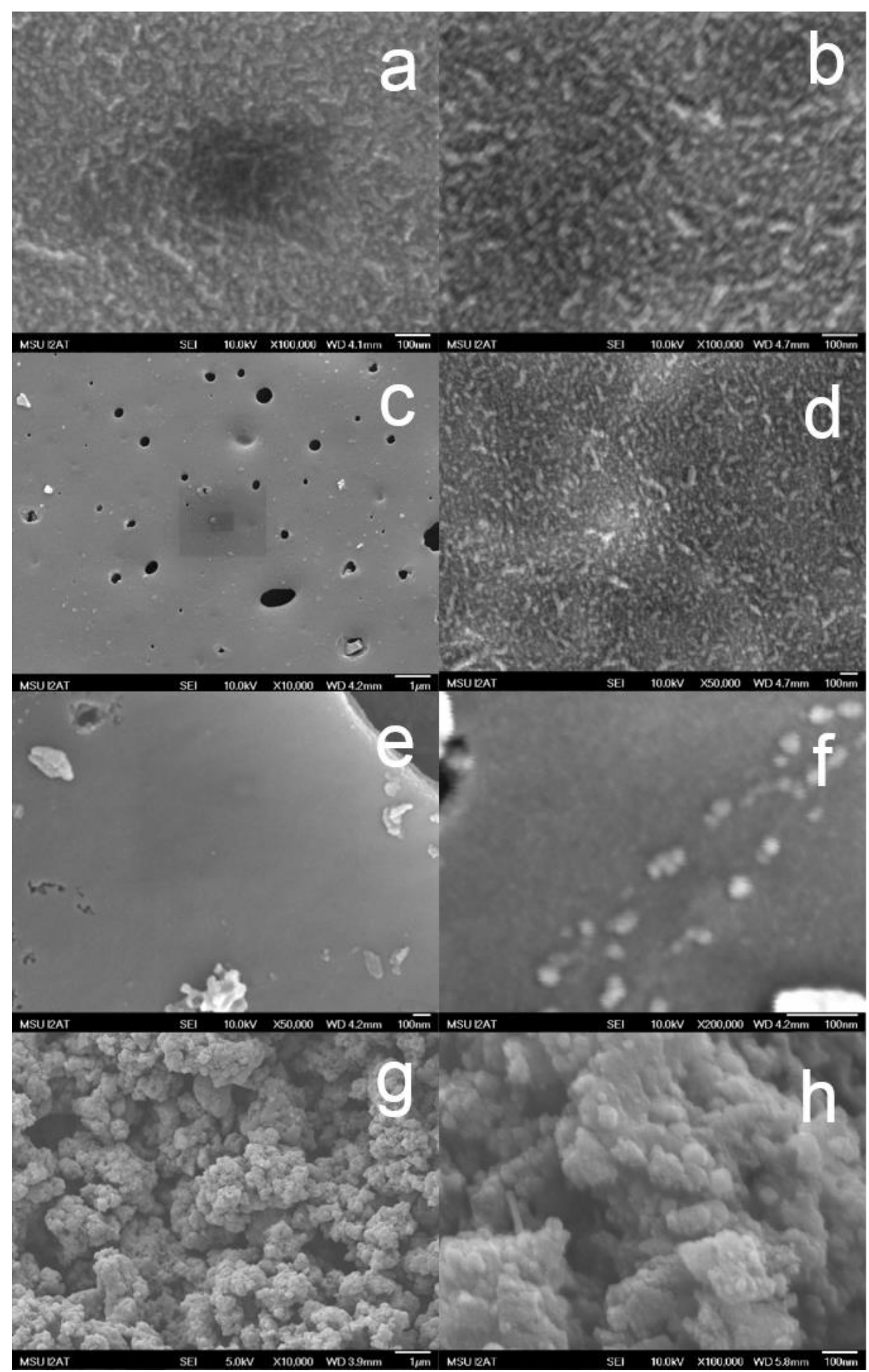

Figure 5. Scanning electron microscope images of four iron source (iron(II) sulfate (a,b) iron(II) chloride $(\mathbf{c}, \mathbf{d})$, iron(III) chloride $(\mathbf{e}, \mathbf{f})$ and iron nitrate $(\mathbf{g}, \mathbf{h}))$ promoted kraft lignin samples thermally treated at $1000^{\circ} \mathrm{C}$ for $1 \mathrm{~h}$ under an argon flow. 

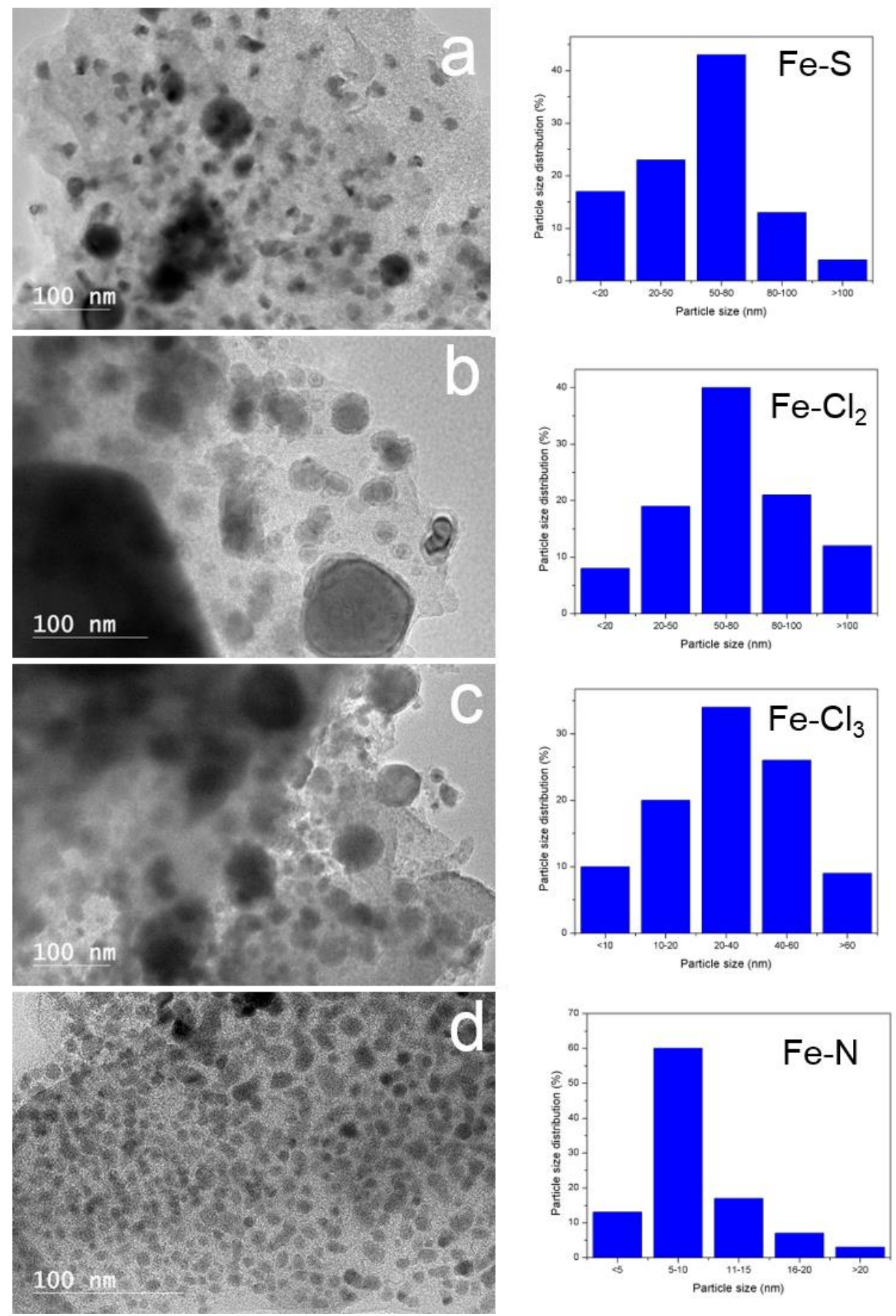

Figure 6. High resolution transmission electron microscope images of four iron sources (iron(II) sulfate (a) iron(II) chloride (b), iron(III) chloride (c) and iron nitrate (d)) promoted kraft lignin after thermal-treated at $1000{ }^{\circ} \mathrm{C}$ for $1 \mathrm{~h}$ under an argon flow.

\section{Discussion}

The elemental composition of lignin varies from species to species but in general, there are $\sim 60 \%$ of carbon, $4-6 \%$ of hydrogen, $28-31 \%$ of oxygen and $1 \%$ of ash [22]. Irons have shown a high activity as catalysts in catalytic conversion of solid carbon to graphite-based materials [23]. A major issue in catalytic graphitization of solid carbon sources including lignin is the contact degree between raw carbon materials and the catalyst [24]. When an iron salt is used as the iron source for a catalyst, the simple mixing of the iron salt dissolved in a solvent with lignin in the powder form is assumed that 
the iron can be easily distributed over the surface of lignin. This is because in general an iron salt has a relative low melting point. Therefore, dissolving the iron salt in a solvent can form a uniform solution. The initial distribution of an iron salt solution in lignin should be homogeneous, therefore, the iron as the catalyst can penetrate the lignin matrix under the catalytic thermal conditions and thus iron ions anchored at reacting carbon sites. This can be achieved only when a proper method is employed to achieve high iron dispersion over lignin.

Generally, an iron-solid biomass precursor is prepared using the impregnation method, that is, typically a dry biomass material such as lignin is added to the iron salt solution. After mixed, the iron salt solution is absorbed through the capillary forces inside the pores of the solid biomass material. Metal ions will further diffuse into biomass matrix and be anchored there through bonding to oxygen-containing groups in biomass.

Lignin is a 3-D complex organic polymer with huge molecules and while kraft lignin has a relative high hydrophobicity. Iron salt aqueous solution is repelled from kraft lignin molecules. It is very difficult for iron ions in an aqueous solution to penetrate into lignin particles. Using a traditional impregnation method will yield a poor contact degree of catalyst-lignin in general [25]. To uniformly blend iron salt with kraft lignin, iron-kraft lignin precursors were prepared in this experiment through a 'co-precipitation' technique, that is, both kraft lignin and iron salt first pre-dissolved in a solvent separately. Iron salts were dissolved in de-ionized (DI) water, while kraft lignin was dissolved in tetrahydrofuran (THF). Both solutions were then carefully mixed, iron salt and lignin would uniformly precipitate as a solid from the solvents. The iron-lignin precursors were achieved after vaporizing the solvents.

It was observed in this work that the catalytic performance in graphitization of kraft lignin was significantly affected by irons from different iron salts. The catalytic performance of four iron salts evaluated as iron sources for catalysts in this work was rated at the order of $\mathrm{Fe}-\mathrm{N}>\mathrm{Fe}-\mathrm{S}>\mathrm{Fe}-\mathrm{Cl}_{3}>$ $\mathrm{Fe}-\mathrm{Cl}_{2}$ from better to worse. The catalytic performance of a catalyst depends on the dispersion of the iron in the Fe-lignin system. The catalyst dispersion can potentially be improved by two methods in catalyst-lignin systems: (1) improving contact between lignin and catalyst during the initial stages of preparing a Fe-lignin precursor and (2) optimizing the physical properties of a catalyst, that is, increasing its surface area through reducing its particle size, or crystallite size [26]. However, sintering or agglomeration was observed for $\mathrm{Fe}-\mathrm{Cl}_{2}$ and $\mathrm{Fe}-\mathrm{Cl}_{3}$ prepared $\mathrm{Fe}$-lignin samples under catalytic graphitization process conditions. Four different iron salts evaluated yielding different iron dispersions in lignin could be because of iron salt properties like iron salt solubility in solvent (usually water), ionized iron properties in water, iron salt melting temperature, iron salt decomposition temperature, iron-lignin bonding strength as well as anion properties in the iron salts. These parameters of iron precursor properties affecting the structure of iron-lignin precursors and final catalytic performance on graphitization of kraft lignin were discussed as followings.

\subsection{The Solubility and the Hydration Properties of Iron Ions}

The dispersion of iron ions in lignin and the formation of iron-lignin complex are typically the first step in the preparation of Fe-lignin precursors $[9,10]$. While the masses of $\mathrm{Fe}^{2+}$ and $\mathrm{Fe}^{3+}$ are practically the same but the ionic radii of the ions differ considerably $\left(0.92 \AA\right.$ for $\mathrm{Fe}^{2+}$ and $0.79 \AA$ for $\mathrm{Fe}^{3+}$ ) because of the different charge states. $\mathrm{Fe}^{3+}$ having a much higher charge density can substantially cause a different hydration behavior compared to $\mathrm{Fe}^{2+}$. Different hydrated complex iron ions will form when iron salts solvate in water [27]. In $\mathrm{Fe}\left(\mathrm{NO}_{3}\right)_{3}$ aqueous solution, iron ions mainly exist as the octahedral hexa-aqua complex $\left[\mathrm{Fe}\left(\mathrm{H}_{2} \mathrm{O}\right)_{6}\right]^{3+}[28$,29]. Similar to that of iron nitrate, the iron(II) sulfate dissolves in water to give the similar aquo-complex $\left[\mathrm{Fe}\left(\mathrm{H}_{2} \mathrm{O}\right)_{6}\right]^{2+}$, which has octahedral molecular geometry. For the $\mathrm{FeCl}_{2}$ aqueous solution, besides the octahedral hexa-aqua complex $\left[\mathrm{Fe}\left(\mathrm{H}_{2} \mathrm{O}\right)_{6}\right]^{2+}$, several chloro-complex species are identified in acidic solutions of ferrous chloride [30], which are: octahedral monochloro-complex $\left[\mathrm{Fe}\left(\mathrm{H}_{2} \mathrm{O}\right)_{5} \mathrm{Cl}\right]^{+}$, dichloro-complex $\left[\mathrm{Fe}\left(\mathrm{H}_{2} \mathrm{O}\right)_{4} \mathrm{Cl}_{2}\right]$ and tetrahedral tetrachlorocomplex $\left[\mathrm{FeCl}_{4}\right]^{2-}$. The latter species, however, is formed exclusively at very high chloride 
excesses and/or high temperatures. Similarly, the complexes formed by ferric chloride $\left(\mathrm{FeCl}_{3}\right)$ are: octahedral hexaaqua complex $\left[\mathrm{Fe}\left(\mathrm{H}_{2} \mathrm{O}\right)_{6}\right]^{3+}$, monochlorocomplex $\left[\mathrm{Fe}\left(\mathrm{H}_{2} \mathrm{O}\right)_{5} \mathrm{Cl}\right]^{2+}$, dichloro-complex trans- $\left[\mathrm{Fe}\left(\mathrm{H}_{2} \mathrm{O}\right)_{4} \mathrm{Cl}_{2}\right]^{+}$, trichloro-complex $\left[\mathrm{Fe}\left(\mathrm{H}_{2} \mathrm{O}\right)_{3} \mathrm{Cl}_{3}\right]$ and tetrahedral tetrachlorocomplex $\left[\mathrm{FeCl}_{4}\right]^{-}$. Correspondingly to the ferrous salt, the highest order chloro-species is only found at high chloride excesses and/or high temperatures. These solvated iron ions have different charge density and radius. Of these solvated iron complexes, the octahedral hexa-aqua complex $\left[\mathrm{Fe}\left(\mathrm{H}_{2} \mathrm{O}\right)_{6}\right]^{3+}$ has the highest charge density and smallest ionic radii, while the chlorocomplexes have a relative lower charge density and larger ionic radii. The higher charge density and smaller ionic radii, the stronger tendency of iron ions to bonding with oxygen-containing groups in lignin when they are contacting. Therefore, it is easy for $\left[\mathrm{Fe}\left(\mathrm{H}_{2} \mathrm{O}\right)_{6}\right]^{3+}$ to penetrate onto lignin molecules and to be uniformly distributed in catalyst-lignin precursors. While the links between chlorocomplexes and lignin are weak and the distribution of these chloride-containing iron precursors is poor in lignin.

\subsection{Thermal Stability of Iron Precursors}

The decomposition of Fe-lignin precursors is the next step (after dispersion of Fe ions onto lignin and drying) before the graphitization of kraft lignin. The decomposition of Fe-lignin precursors usually results in the formation of iron oxide species which can be converted to the active iron metal phases in kraft lignin matrix. Previous literature works [31] suggested that the decomposition of metal precursors at milder conditions generally leads to a higher metal dispersion. This means that iron salt precursors decomposed at a lower temperature will result in better iron dispersion and catalytic performance. The iron salts investigated in this work are $\mathrm{Fe}\left(\mathrm{NO}_{3}\right)_{3}, \mathrm{FeSO}_{4}, \mathrm{FeCl}_{3}$ and $\mathrm{FeCl}_{2}$. Of these iron salts, iron nitrate will be easily broken between $100-250{ }^{\circ} \mathrm{C}$, release gaseous $\mathrm{H}_{2} \mathrm{O}, \mathrm{HNO}_{3}, \mathrm{NO}$ and $\mathrm{NO}_{2}$ and leave $\mathrm{Fe}_{2} \mathrm{O}_{3}$ as solid residues. When heated, iron(II) sulfate first loses its water of crystallization and original crystals are converted into an anhydrous solid [32]. The TGA curves of Fe-S prepared samples showed the initial dehydration of $\mathrm{FeSO}_{4} \cdot 7 \mathrm{H}_{2} \mathrm{O}$ occurred at the temperature up to $200{ }^{\circ} \mathrm{C}\left(\mathrm{FeSO}_{4} \cdot 7 \mathrm{H}_{2} \mathrm{O} \rightarrow \mathrm{FeSO}_{4}+7 \mathrm{H}_{2} \mathrm{O}\right)$. When further heated, the anhydrous material decomposes and releases sulfur dioxide and sulfur trioxide, leaving a solid iron(III) oxide [33]. The decomposition of sulfate initiates around $500{ }^{\circ} \mathrm{C}$. TGA curve demonstrated a sharp decrease in weight at $500{ }^{\circ} \mathrm{C}$ for Fe-S prepared samples, followed by a slower decomposition at 500-600 ${ }^{\circ} \mathrm{C}$. Other researchers observed a sharp decrease in weight because of the decomposition in the temperature range of $550-625^{\circ} \mathrm{C}$ for $\mathrm{FeSO}_{4}$ prepared samples.

At the higher temperature of $700{ }^{\circ} \mathrm{C}$, anhydrous $\mathrm{FeCl}_{3}$ decomposes and forms ferrous chloride [34].

$\mathrm{FeCl}_{3}$ above $700{ }^{\circ} \mathrm{C} \rightarrow 2 \mathrm{FeCl}_{2}+\mathrm{Cl}_{2}$

But $\mathrm{Fe}(\mathrm{III})$ chloride hydrate $\left(\mathrm{FeCl}_{3} \cdot \mathrm{xH}_{2} \mathrm{O}\right)$ can proceed simultaneously by both dehydration and hydrolysis at the temperature above $100{ }^{\circ} \mathrm{C}\left(\mathrm{FeCl}_{3}+2 \mathrm{H}_{2} \mathrm{O} \rightarrow \mathrm{Fe}(\mathrm{OH})_{2} \mathrm{Cl}+2 \mathrm{HCl}\right.$ or $\mathrm{FeCl}_{3}+3 \mathrm{H}_{2} \mathrm{O} \rightarrow$ $\left.\mathrm{Fe}(\mathrm{OH})_{3}+3 \mathrm{HCl}\right)$. In the temperature range of $250-300{ }^{\circ} \mathrm{C}$, a stable hydrated $\mathrm{Fe}(\mathrm{OH})_{2} \mathrm{Cl}$ is formed [33]. Around $400{ }^{\circ} \mathrm{C}, \mathrm{Fe}(\mathrm{OH})_{2} \mathrm{Cl}$ continues to decompose and form mostly $\mathrm{Fe}_{2} \mathrm{O}_{3}$, which however retains some $\mathrm{OH}$ groups and $\mathrm{Cl}-$ ions [35].

Similar to $\mathrm{FeCl}_{3}, \mathrm{FeCl}_{2}$ (anhydrous) itself is thermally stable under temperatures up to $1000{ }^{\circ} \mathrm{C}$, its hydrate $\left(\mathrm{FeCl}_{2} \cdot \mathrm{xH}_{2} \mathrm{O}\right)$ can undergo partial hydrolysis or thermal decomposition to $\mathrm{Fe}_{3} \mathrm{O}_{4}, \mathrm{HCl}$ and $\mathrm{H}_{2}$ (reaction: $3 \mathrm{FeCl}_{2}+4 \mathrm{H}_{2} \mathrm{O} \rightarrow \mathrm{Fe}_{3} \mathrm{O}_{4}+6 \mathrm{HCl}+\mathrm{H}_{2}$ ) between 550 and $800{ }^{\circ} \mathrm{C}$ [36].

TGA and TPD-MS results illustrate that Fe-N prepared samples decompose at $237^{\circ} \mathrm{C}$, which is the lowest among four iron salts evaluated, that is, $300{ }^{\circ} \mathrm{C}$ for $\mathrm{Fe}-\mathrm{Cl}_{3}, 323^{\circ} \mathrm{C}$ for $\mathrm{Fe}^{-} \mathrm{Cl}_{2}$ and $449{ }^{\circ} \mathrm{C}$ for $\mathrm{Fe}-\mathrm{S}$ prepared samples. The lower iron nitrate decomposition temperature enhances iron dispersion, which is consistent with the XRD (Figure 3), SEM (Figure 5) and TEM (Figure 6) results. 


\subsection{Interaction of Iron with Functional Groups in Kraft Lignin}

The effects of iron precursors on solid carbon yields during de-polymerization and initial carbonization may also be explained by considering the association of Fe with the lignin structure when preparing Fe-lignin precursors. Fe ions $\left(\mathrm{Fe}^{3+}\right.$ and $\left.\mathrm{Fe}^{2+}\right)$ may be coordinated to a series of oxygen-containing ligands in lignin including $\mathrm{O}^{2-}, \mathrm{OH}^{-}, \mathrm{H}_{2} \mathrm{O},-\mathrm{C}=\mathrm{O}, \mathrm{C}-\mathrm{O}-\mathrm{C}$ and $-\mathrm{COO}-$. Thus, Fe in lignin will greatly change the macromolecular structure of lignin by bringing the coordination sites closer and making the lignin structure tighter. Firstly, irons stabilize the oxygen-containing functional groups (such as carboxylic groups) which they are linked with, leading to increased contact degree between Fe as the catalyst and lignin. Secondly, irons enhance the thermal cracking down and de-polymerization of lignin, yielding the remove of most of oxygen and hydrogen via catalytic thermal process and generating solid carbon structures around iron particles. During the catalytic thermal process, the bonding between Fe ions and lignin structure will break down and iron ions would be converted into metallic or other forms with increasing temperature. The carbon structures around iron particles will also further decompose to produce more gases. The iron had different effects on the gas production. The gas fraction was $44.8 \%, 45 \%, 46.3 \%$ and $50.7 \%$ for $\mathrm{Fe}_{-} \mathrm{Cl}_{3}, \mathrm{Fe}-\mathrm{Cl}_{2}, \mathrm{Fe}-\mathrm{S}$ and $\mathrm{Fe}-\mathrm{N}$ prepared samples, respectively. The $\mathrm{H}_{2} \mathrm{~S}$ evolution profiles (Figure $2 \mathrm{~h}$ ) showed no $\mathrm{H}_{2} \mathrm{~S}$ detected in Fe-N samples and also elemental data proved the highest sulfur content in Fe-N samples. These further proved the highest dispersion iron in Fe-N samples, which would simultaneously absorb $\mathrm{H}_{2} \mathrm{~S}$ released from kraft lignin structure during the catalytic decomposition process.

\subsection{Impacts of Chlorine on Iron Catalyst}

Chlorine is considered to be a very strong poison to metal catalysts, particularly in transitional metal catalysts for F-T process [37] and ammonia synthesis [38]. A significant amount of residual $\mathrm{Cl}^{-}$ ions (Table 2) was observed in $\mathrm{Fe}-\mathrm{Cl}_{2}$ and $\mathrm{Fe}-\mathrm{Cl}_{3}$ prepared samples during the catalytic decomposition process (Figure $2 \mathrm{i}$ ). The presence of chlorine in Fe-lignin samples could strongly alter iron catalytic properties. Residual chlorine, which remained in the catalysts after the thermal decomposition, can have several impacts on the properties and performance of the catalysts [39]. First, the existence of chloride on metal surfaces will accelerate the agglomeration/sintering of metal particles [40]. This one might relate to the formation of iron-chlorine compounds on iron particle surfaces. Iron particles with a layer of $\mathrm{Fe}-\mathrm{Cl}$ on surfaces have a tendency to merge and agglomerate to form larger size particles. This phenomenon could cause an increase in the size of iron crystallites and thus, a decrease of the surface area and iron dispersion. The second possible mechanism is also based on $\mathrm{Fe}-\mathrm{Cl}$ formation. The formation of Fe-C phases between the active iron metal and the carbon species can be affected by the presence of chlorine. Iron-chlorine compounds are very stable at a high temperature, a thin film of $\mathrm{FeCl}_{2}$ on metal iron surfaces formed when a molecular beam of carbon tetrachloride bombarded on an iron film surface in ultrahigh vacuum at $780{ }^{\circ} \mathrm{C}$ [41]. The formation of $\mathrm{FeCl}_{2}$ thin film will be a diffusion barrier for preventing carbon atoms to be transferred into and interact with iron particles and then the growth of graphene structure can be stopped. Third, experimental results indicate that the formation of graphene structures from solid carbon sources is partially related to the carbonaceous gases (such as $\mathrm{CH}_{4}$ or $\mathrm{CO}$ ) generated from the decomposition of solid carbon feedstock. Residue chloride adsorbed on catalyst surfaces will deactivate iron active sites by preventing the adsorption of carbonaceous gas molecules [42].

\section{Conclusions}

In the present study, the effect of irons containing different anions like nitrate and chloride on the catalytic thermal graphitization of kraft lignin to graphene-based materials was investigated. Four iron salts (iron(III) nitrate, iron(II) chloride, iron(III) chloride and iron(II) sulfate) were used as iron sources. The catalytic decomposition of iron-promoted lignin samples was examined using TGA and TPD experiments. The thermally treated Fe-lignin samples were measured and characterized by elemental 
analysis, XRD, Raman, SEM and HRTEM. It was found that four different iron salts influenced the states and dispersion of iron species in Fe-lignin samples. Among four iron salts studied, iron nitrate was the most active one, while both the iron(III) chloride and iron(II) chloride showed poor activity. The residual chlorine presented over iron surfaces might prevent the interaction of iron with functional groups in lignin, decrease iron dispersion and reduce activity of irons as the catalyst. The better activity on the catalytic decomposition of iron nitrate-lignin could be attributed to the highly dispersed iron nanoparticles and stronger iron-lignin interaction. The use of iron(III) nitrate as an iron source for the catalyst for iron-kraft lignin precursors gave higher iron dispersions than the catalysts prepared from iron(II) chloride and iron(III) chloride.

Author Contributions: Conceptualization, Q.Y. and Z.C.; Methodology, Q.Y. and J.L.; Investigation, Q.Y., J.L. and X.Z.; Writing-Original Draft Preparation, Q.Y.; Writing-Review \& Editing, J.L. and J.Z.; Supervision, J.Z. and Z.C.; Project Administration, Z.C.; Funding Acquisition, J.Z. and Z.C.

Funding: This research was funded by USDA Forest Service.

Acknowledgments: This work was supported by the USDA Forest Service through Grant No. 16-JV-11111124-075. The authors would like to acknowledge Domtar Corp., North Carolina for providing kraft lignin for this study. The assistance of Amanda Lawrence of the Institute for Imaging \& Analytical Technologies ( $\left.{ }^{2} \mathrm{AT}\right)$ at Mississippi State University is gratefully acknowledged. Editorial assistance provided by Neil Gribbins of USDA Forest Products Laboratory.

Conflicts of Interest: The authors declare no conflict of interest.

\section{References}

1. Aro, T.; Fatehi, P. Production and Application of Lignosulfonates and Sulfonated Lignin. ChemSusChem 2017, 10, 1861-1877. [CrossRef] [PubMed]

2. Doherty, W.O.S.; Mousavioun, P.; Fellows, C.M. Value-adding to cellulosic ethanol: Lignin polymers. Ind. Crop. Prod. 2011, 33, 259-276. [CrossRef]

3. Ruiz-Rosas, R.; Valero-Romero, M.J.; Salinas-Torres, D.; Rodríguez-Mirasol, J.; Cordero, T.; Morallón, E.; Cazorla-Amorós, D. Electrochemical Performance of Hierarchical Porous Carbon Materials Obtained from the Infiltration of Lignin into Zeolite Templates. ChemSusChem 2014, 7, 1458-1467. [CrossRef] [PubMed]

4. Otani, S.; Fukuoka, Y.; Igarashi, B.; Sasaki, K. Method for Producing Carbonized Lignin Fiber. U.S. Patent 3461082 A, 12 August 1969.

5. Suhas, P.J.M.; Carrott, M.M.L.; Carrott, R. Lignin-From natural adsorbent to activated carbon: A review. Bioresour. Technol. 2007, 98, 2301-2312. [CrossRef] [PubMed]

6. $\quad$ Leng, W.; Barnes, H.M.; Yan, Q.; Cai, Z.; Zhang, J. Low temperature synthesis of graphene-encapsulated copper nanoparticles from kraft lignin. Mater. Lett. 2016, 185, 131-134. [CrossRef]

7. Zhang, X.; Yan, Q.; Li, J.; Cai, Z.; Zhang, J. Temperature effects on formation of carbon-based nanomaterials from kraft lignin. Mater. Lett. 2017, 203, 42-45. [CrossRef]

8. Zhang, J.; Yan, Q.; Cai, Z. Methods for Synthesizing Graphene from a Lignin Source. U.S. Patent US20170113936 A1, 8 January 2017.

9. Yan, Q.; Zhang, X.; Li, J.; Wang, C.; Zhang, J.; Cai, Z. Catalytic conversion of Kraft lignin to bio-multilayer graphene materials under different atmospheres. J. Mater. Sci. 2018, 53, 8020-8029. [CrossRef]

10. Yan, Q. Catalytic Thermal Conversion of Kraft Lignin to Multi-Layer Graphene Materials. Ph.D. Thesis, Mississippi State University, Starkville, MS, USA, 2017.

11. Yan, Q.; Li, J.; Zhang, X.; Wang, C.; Zhang, J.; Cai, Z. Catalytic graphitization of kraft lignin to graphene-based structures with four different transitional metals. J. Nanopart. Res. 2018, 20, 223. [CrossRef]

12. Takehira, K.; Shishido, T. Preparation of supported metal catalysts starting from hydrotalcites as the precursors and their improvements by adopting "memory effect". Catal. Surv. Asia 2007, 11, 1-30. [CrossRef]

13. Perry, D.L. Handbook of Inorganic Compounds; Taylor \& Francis: Boca Raton, FL, USA, 2011.

14. Fígoll, N.S.; Sad, M.R.; Beltraminl, J.N.; Jablonski, E.L.; Parera, J.M. Influence of the Chlorine Content on the Behavior of Catalysts for n-Heptane Reforming. Ind. Eng. Chem. Prod. Res. Dev. 1980, 19, 545-551. [CrossRef]

15. Patterson, A. The Scherrer Formula for X-ray Particle Size Determination. Phys. Rev. 1939, 56, 978-982. [CrossRef] 
16. Jenkins, R.; Snyder, R.L. Introduction to X-ray Powder Diffractometry; John Wiley \& Sons Inc.: New York, NY, USA, 1996; pp. 89-91; ISBN 0-471-51339-3.

17. Pimenta, M.A.; Dresselhaus, G.; Dresselhaus, M.S.; Cançado, L.G.; Jorio, A.; Saito, R. Studying disorder in graphite-based systems by Raman spectroscopy. Phys. Chem. Chem. Phys. 2007, 9, 1276-1290. [CrossRef] [PubMed]

18. Bassilakis, R.; Carangelo, R.M.; Wójtowicz, M.A. TG-FTIR analysis of biomass pyrolysis. Fuel 2001, 80, 1765-1786. [CrossRef]

19. Freudenberg, K.; Neish, A.C. Constitution and Biosynthesis of Lignin; Springer: Berlin/Heidelberg, Germany; New York, NY, USA, 1968.

20. Melnikov, P.; Nascimento, V.A.; Arkhangelsky, I.V.; Zanoni Consolo, L.Z.; de Oliveira, L.C.S. Thermal decomposition mechanism of iron(III) nitrate and characterization of intermediate products by the technique of computerized modeling. J. Therm. Anal. Calorim. 2014, 115, 145-151. [CrossRef]

21. Gallagher, P.K.; Johnson, D.W.; Schrey, F. Thermal Decomposition of Iron(II) Sulfates. J. Am. Ceram. Soc. 1970, 53, 666-670. [CrossRef]

22. King, H.-H.; Solomon, P.R.; Avni, E.; Coughlin, R.W. Modeling Tar Composition in Lignin Pyrolysis. In Proceedings of the Symposium on Mathematical Modeling of Biomass Pyrolysis Phenomena, Washington, DC, USA, 1 January 1983; pp. 319-329.

23. Hirano, K.; Kouzu, M.; Okada, T.; Kobayashi, M.; Ikenaga, N.; Suzuki, T. Catalytic activity of iron compounds for coal liquefaction. Fuel 1999, 78, 1867-1873. [CrossRef]

24. Demir, M.; Kahveci, Z.; Aksoy, B.; Palapati, N.K.R.; Subramanian, A.; Cullinan, H.T.; El-Kaderi, H.M.; Harris, C.T.; Gupta, R.B. Graphitic Biocarbon from Metal-Catalyzed Hydrothermal Carbonization of Lignin. Ind. Eng. Chem. Res. 2015, 54, 10731-10739. [CrossRef]

25. Zakzeski, J.; Bruijnincx, P.C.A.; Jongerius, A.L.; Weckhuysen, B.M. The Catalytic Valorization of Lignin for the Production of Renewable Chemicals. Chem. Rev. 2010, 110, 3552-3599. [CrossRef] [PubMed]

26. Ertl, G.; Knozinger, H.; Schüth, F.; Weitkamp, J. Handbook of Heterogeneous Catalysis, 2nd ed.; Wiley: Hoboken, NJ, USA, 2008; Volume 8, pp. 4270-4278; ISBN 3527312412, 9783527312412.

27. Ogden, M.I.; Beer, P.D. Water \& O-Donor Ligands. In Encyclopedia of Inorganic Chemistry; Wiley-VCH: Weinheim, Germany, 2006.

28. Lincoln, S.F.; Richens, D.T.; Sykes, A.G. Metal Aqua Ions. In Comprehensive Coordination Chemistry II; Elsevier Science: London, UK, 1987; Volume 1, pp. 515-555.

29. Sham, T.K.; Hastings, J.B.; Perlman, M.L. Structure and dynamic behavior of transition-metal ions in aqueous solution: An EXAFS study of electron-exchange reactions. J. Am. Chem. Soc. 1980, 102, 5904-5906. [CrossRef]

30. Böhm, F.; Sharma, V.; Schwaab, G.; Havenith, M. The low frequency modes of solvated ions and ion pairs in aqueous electrolyte solutions: Iron(II) and iron(III) chloride. Phys. Chem. Chem. Phys. 2015, 7, 19582-19591. [CrossRef] [PubMed]

31. Sietsma, J.R.A.; Meeldijk, J.D.; den Breejen, J.P.; Versluijs-Helder, M.; van Dillen, A.J.; de Jongh, P.E.; de Jong, K.P. The Preparation of Supported $\mathrm{NiO}$ and $\mathrm{Co}_{3} \mathrm{O}_{4}$ Nanoparticles by the Nitric Oxide Controlled Thermal Decomposition of Nitrates. Angew. Chem. Int. Ed. 2007, 46, 4547-4549. [CrossRef] [PubMed]

32. Johnson, D.W.; Gallagher, P.K. Kinetics of the decomposition of freeze-dried iron(II) sulfate. J. Phys. Chem. 1971, 75, 1179-1185. [CrossRef]

33. Oliveira, A.C.; Marchetti, G.S.; do Carmo Rangel, M. The effect of the starting material on the thermal decomposition of iron oxyhydroxides. J. Therm. Anal. Calorim. 2003, 73, 233-240. [CrossRef]

34. Wang, L.; Guo, C.; Zhu, Y.; Zhou, J.; Fan, L.; Qian, Y. A FeCl 2 -graphite sandwich composite with $\mathrm{Cl}$ doping in graphite layers: A new anode material for high-performance Li-ion batteries. Nanoscale 2014, 6, 14174-14179. [CrossRef] [PubMed]

35. Kanungo, S.B.; Mishra, S.K. Thermal dehydration and decomposition of $\mathrm{FeCl}_{3} \cdot \mathrm{xH}_{2}$ O. J. Therm. Anal. 1996, 46, 1487-1500. [CrossRef]

36. Nihira, Y.; Nomura, T. Magnetite Formation by Thermal Decomposition of $\mathrm{FeCl}_{2}$. J. Jpn. Soc. Powder Powder Metall. 1995, 42, 598-602. [CrossRef]

37. Lee, J.-F.; Lee, M.-D.; Tseng, P.-K. Fischer-Tropsch synthesis on supported iron catalysts prepared from iron(III) chloride pretreatment effects on phase changes and catalytic properties. Appl. Catal. 1989, 52, 193-209. [CrossRef] 
38. Arabczyk, W.; Narkiewicz, U.; Moszyński, D. Chlorine as a poison of the fused iron catalyst for ammonia synthesis. Appl. Catal. A-Gen. 1996, 134, 331-338. [CrossRef]

39. Consonni, M.; Jokic, D.; Murzin, Y.D.; Touroude, R. High Performances of Pt/ZnO Catalysts in Selective Hydrogenation of Crotonaldehyde. J. Catal. 1999, 188, 165-175. [CrossRef]

40. Calvin, H. Bartholomew, Mechanisms of catalyst deactivation. Appl. Catal. A-Gen. 2001, 212, 17-60.

41. Lara, J.; Tysoe, W.T. The surface and tribological chemistry of carbon tetrachloride on iron. Tribol. Lett. 1999, 6, 195-198. [CrossRef]

42. Forzatti, P.; Lietti, L. Catalyst deactivation. Catal. Today 1999, 52, 165-181. [CrossRef]

(C) 2018 by the authors. Licensee MDPI, Basel, Switzerland. This article is an open access article distributed under the terms and conditions of the Creative Commons Attribution (CC BY) license (http:/ / creativecommons.org/licenses/by/4.0/). 